\title{
Gestão geoambiental de bacias hidrográficas: os sistemas geológicos como fase inicial de decisão para uso da terra
}

\author{
Paulo Pereira Martins Junior ${ }^{1,2 *}$, António Francisco Sá e Melo Marques ${ }^{1}$, João Álvaro Carneiro ${ }^{1}$, \\ Vitor Vieira Vasconcelos', Leandro Arb d'Abreu Novaes', Sidney Augusto Gonçalves Rosa ${ }^{1}$
}

\begin{abstract}
Resumo Após a cartografia da bacia do Rio Paracatu (Noroeste de Minas Gerais) ser atualizada em escala de 1:250.000, foi possível elaborar a lógica para a metodologia de gestão geoambiental/geossistemas, como parte de uma ampla metodologia de gestão, em elaboração desde 1998. Apresenta-se como primeira etapa a verificação das relações entre rochas, geoformas e solos com as quais se exploram possibilidades e potencialidades de usos da terra para produção agrícola, florestal, industrial, rural, energética e de obras civis. Com o quadro de potencialidades fundamentado sobre os geossistemas, foi possível então realizar uma análise avaliativa das condições de acerto ou inconveniência dos usos atuais da terra, as possibilidades de expansão de usos e as necessidades de mitigação sob o ponto de vista da estabilidade do substrato. Com a cartografia na escala de 1:250.000 pode-se estabelecer uma visão regional e fornecer indicativos para estudos em escala local e a tomada de decisão que envolve ainda um conjunto de outras ciências, engenharias e modelos econométricos. Este artigo apresenta os procedimentos dessa primeira etapa de auxílio à elaboração de decisões, passo a passo.
\end{abstract}

Palavras-chave: Bacia do Rio Paracatu; gestão geoambiental; metodologia; primeira etapa de procedimentos; geologia; geomorfologia; pedologia.

\begin{abstract}
Geo-environmental management of watersheds: the geological systems as the initial decision to land use. After the mapping of the Paracatu River basin (Northwestern Minas Gerais, Brazil) was updated on a scale of 1:250,000, it was possible to elaborate the rationale for the methodology of geo-environmental/geosystems management as part of a broad management methodology, under development since 1998. It presents as the first step to verify the relationship between rocks, landforms, and soils with which one can explore possibilities and potential land use for agricultural production, forestry, rural industrial, energy production, and civil works. With the framework of potentials based on geosystems, it was possible to make an evaluation analysis about the terms of settlement or inconvenience of the land current uses, the possibilities for expansion of uses, and the requirements for mitigation under the terms of the substrate stability. With the mapping at the 1:250,000 scale, it was possible to establish a regional vision provide the indicative scale studies and local decision-making that still involves a number of other sciences, engineering as well as the econometric models. This article presented the procedures of the first stage of the aid business decision making, step-by-step.
\end{abstract}

Keywords: Paracatu River Basin; geo-environmental management; methodology; first phase of procedures; geology; geomorphology; soil science.

\section{INTRODUÇÃO A questão dos métodos de} gestão das bacias hidrográficas, vistos a partir dos problemas, objetivos e constatação de eficiências administrativa e eficácia de resultados, está distante de ser devidamente proposta, executada e avaliada positivamente no Brasil. Neste estudo dá-se sequência ao desenvolvimento da proposta metodológica para as geociências agrárias e ambientais (Martins Jr. 1998). A Bacia do Paracatu com $45.060 \mathrm{~km}^{2}$, tomada como estudo de caso, é a maior sub-bacia do Vale do São Francisco. Sua área é constituída por um conjunto de rochas pré-cambrianas e por uma sequência de depósitos sedimentares de idade cretácea, além de sedimentos e coberturas detríticas do Terciário-Quaternário.

Problemas São vários os problemas a que se propõe responder nesta inquirição desenvolvida a partir de 2007 (Martins Jr. et al. 2006). Existe alguma ordem ideal para se tratar com a gestão do uso da terra na totalidade de uma bacia hidrográfica? Se sim, essa ordem ideal pode ser usada em bacias cujos processos de uso e degradação sejam antigos e avançados? Qual a importância relativa das geociências

Projeto CRHA “Conservação de Recursos Hídricos no Âmbito da Gestão Agrícola e Ambiental de Bacias Hidrográficas” (2003-2006/ MCT-FINEP-Fundo Setorial CT-Hidro-2002) e Projeto SACD "Sistemas de Arquitetura de Conhecimentos e de Auxílio à Decisão na Gestão Geoambiental e Econômica de Bacias Hidrográficas e Propriedades Rurais” (2010-2012/FAPEMIG).

${ }^{1}$ Fundação Centro Tecnológico de Minas Gerais, Belo Horizonte (MG), Brasil. E-mail: maerteyn@gmail.com

${ }^{2}$ Departamento de Geologia, Programa de Pós-graduação na Universidade Federal de Ouro Preto - UFOP, Ouro Preto (MG), Brasil.

*Autor correspondente. 
agrárias e ambientais - GAA (Martins Jr. 1998) para modelar os processos de gestão? Quais alguns dos aspectos fundamentais trazidos pelos conhecimentos científicos das geociências, que podem ser considerados irredutíveis e condição sine qua non de sucesso na atividade da gestão geoambiental?

Objetivo Propõe-se apresentar, a partir de cartografia das geociências atualizada para a Bacia do Paracatu, hipóteses para as relações espaciais entre rochas, geoformas e solos por meio dos conceitos e relações entre morfogênese e pedogênese associadas. Tais hipóteses são confrontadas com os dados de compatibilidade superficial do uso da terra, criteriosamente medidos, para a Bacia do Paracatu. Os resultados estão apresentados de modo a responder às perguntas colocadas como problemas. Entrementes, são discutidas também questões sobre como os atributos dos geossistemas podem ser importantes e fundamentais para o planejamento territorial, visando o desenvolvimento econômico sustentável.

\section{METODOLOGIA O Planoroeste II (CETEC} 1981) é a fonte original de referência cartográfica. Essas informações foram digitalizadas e complementadas com bases cartográficas do Serviço Geológico do Brasil (CPRM), do Sistema de Informações Estatísticas e Geográficas do Estado de Goiás (SIEG) e da Fundação Rural Mineira - RURALMINAS (1996). Nesta fase, foi de relevante importância a cooperação com a equipe do Instituto de Geociências Aplicadas de Minas Gerais (IGA). A cartografia de solo foi convertida para o novo Sistema Brasileiro de Classificação de Solos (EMBRAPA 1999), com base nos trabalhos de Marques e Martins Jr. (2004) para a Bacia do Rio Paracatu. Os mapas foram corrigidos com ferramentas topológicas nos softwares ArcView 3.2 e ArgGis 9.2. Para análise da relação espacial entre os temas, foram utilizadas ferramentas básicas de análise espacial, tais como Intersect, Clip e Union. Para as operações de manipulação do banco de dados e matemáticas, foram utilizados, além dos softwares supracitados, os programas MapInfo 9.0 e Excel. Para a discussão da pertinência do estudo ante os problemas citados, utilizou-se uma abordagem epistemológica (Martins Jr. 2000) para testar significados reconhecíveis como irredutíveis e essenciais para a estabilidade de bacias hidrográficas e sustentabilidade temporal das atividades econômicas rurais dentro do modelo fundamental apresentado por Martins Jr. (1998), ao se introduzir a proposição do desenvolvimento sustentável também como campo de conhecimento proposto para as GAA e em sucessivos projetos.

HIPÓTESES Os aspectos gerais e fundamentais das |litoestruturas/geoformas/solos| da Bacia do Paracatu são mostrados como correlações para que se possa aplicar ao desenvolvimento de sistemas inteligentes de auxílio à decisão para ordenamento do território. Para tanto, necessita-se obrigatoriamente dos aspectos de integração cognitiva das seguintes relações:

- Hipótese 1 - as relações sistêmicas entre |rochas/geoformas/solos/circulação hídrica|, em primeira instância, são aspectos geológicos irredutíveis fundamentais.

- Hipótese 2 - a integração daquelas relações sistêmicas da hipótese 1 para ser aplicável a um sistema lógico interdisciplinar de auxílio à decisão deve assentar-se segundo uma lógica que permita trabalhar com associatividades comuns e eventuais e anomalias associativas, as quais passam por uma "tipificação global das respectivas associações cogenéticas" às "perspectivas regionais e locais cogenéticas e anômalas", entre rochas, geoformas e solos.

- Hipótese 3 - com a aplicação de apropriada lógica, deve-se poder caracterizar esboços com "indicações determinantes" para serem consideradas das escalas regionais $\leq 1: 250.000$ às locais, em níveis de sub-bacias da quarta à oitava ordem $\geq 1: 100.000$, e de propriedades rurais de 1:25.000 a 1:5.000 para o auxílio à decisão em várias escalas de observação, decisão e interação entre níveis de decisão para as atividades rurais de quaisquer tipos.

Hipótese 4 - dentro da perspectiva de uma arquitetura de conhecimentos (Martins Jr. 2008), do regional ao local, deve-se tratar como condição fundamental as associações entre rochas, geoformas e solos que sejam, primeiramente, lógicas e cogenéticas, enquanto outras decorrem de transformações geotécnicas, geoquímicas e edafoquímicas mais específicas; nessas, os organismos têm mais importância na gênese e na tipificação de solos, afastando-os de relações clássicas cogenéticas |rochas-solos|, portanto, admite-se que as categorias de solos são uma das instâncias centrais e mais fundamentais para a aproximação em escalas do regional ao local. 


\section{RELAÇÕES GERAIS ENTRE ROCHAS, GEOFORMAS E SOLOS}

\section{Geoformas mais comuns Entre as geoformas} mais comuns existentes em amplas áreas do planeta citam-se: cuestas/hogbacks, plateaux de rochas granulares, relevos kársticos, planícies de inundação, vales encaixados, encostas com pedimentos, plateaux de lateritas e de cangas, quaisquer tipos de superfícies cortadas transversas a rochas dobradas, relevos íngremes com saibros ou saprolitos, colinas arredondadas, relevos aplainados de bacias sedimentares, planaltos rochosos de derrames de lavas, núcleos e vertentes de vulcões atuais ou antigos, planícies costeiras com lagoas como litorais de submersão, litorais de emersão com montanhas e encostas íngremes, áreas com dunas, vertentes com altas declividades $>30 \%$ etc.

A Tab. 1 aponta para estas associações cogenéticas gerais e mais típicas, derivadas dos processos de gênese de geoformas e solos que tenham maior correlação com a rocha portadora numa relação de pedogênese, quando direta.

Rochas e estruturas reológicas As estruturas rúpteis têm algumas propriedades importantes para o auxílio à decisão geoambiental. Aquelas são descontinuidades nas rochas que influem sobre: a estabilidade de taludes, o processo de aprofundamento do intemperismo, a infiltração de água em aquíferos fraturados e/ou dobrados e a formação de saprolitos profundos.

A morfogênese, enquanto processo, é determinante para os encaixes de cursos d'água, áreas de inundação, paredões em planos de falhas, declividades várias das vertentes, áreas preferenciais de erosão etc. Esses aspectos são partes do quadro de auxílio às decisões regional e local para plantios florestais $\mathrm{e}$ escolha de áreas agronômicas, ou para mitigação de áreas degradadas, ou com mau uso, com vistas às atividades econômicas e/ou à mitigação florestal.

Os comitês de bacia hidrográfica, ao planejarem em nível regional, deverão ter um quadro de decisões a serem parametrizadas em função dessas estruturas, relações |rochas/ geoformas/ solos/ circulação hídrica| e com as estruturas dúcteis e rúpteis expostas.

Em relação às estruturas dúcteis, rúpteis e aos tipos de rochas, tais associações seguem os tipos específicos de ambientes geotectônicos que codeterminam a produção de geoformas e relevos e, por conseguinte, algumas ordens e subordens de solos, que, por sua vez, são associadas preferencialmente a determinadas geoformas (Tab. 1), como também são mais afins a determinadas rochas. Muitas variedades de solos são anômalas em relação ao substrato e são de estrita derivação de condições específicas da geodinâmica externa mais recente. Não se pode deixar de levar em conta climas, microclimas e agentes bióticos como eficazes fatores construtores de solos, afora a água em diversos níveis de presença, do ambiente úmido ao inundado.

\section{DISCUSSÃO SOBRE ROCHAS, GEOFORMAS E SOLOS NO PARACATU Para Almeida} (1977), a região de Paracatu se insere na faixa de dobramentos Brasília e abrange pequena porção de uma unidade geotectônica maior, pré-brasiliana, denominada Cráton São Francisco. Em relação aos aspectos estruturais (CETEC 1981), a região em estudo se caracteriza por uma porção central de plataforma estável, limitada a leste e oeste por zonas de deformações marginais. Por plataforma estável entende-se a área cratônica em que as rochas pré-cambrianas apresentam-se, de modo geral, sub-horizontais e com evidências de deformações moderadas, mas algum grau de metamorfismo. Todavia, em alguns locais dessa plataforma, as rochas refletem reativações de falhamentos do embasamento cristalino. As zonas de deformações marginais apresentam dobras e falhas inversas com planos, aproximadamente, paralelos aos limites Sul e Oeste do Cráton do São Francisco.

Rocha O Vale está assentado em um grupo de rochas, que não é notável no que diz respeito à agricultura e à silvicultura. Não obstante, muitos solos do Cerrado regional, uma vez corrigidos e fertilizados, têm oferecido condições excelentes para ser um dos vales de maior produção de grãos no Brasil. As rochas regionais são derivadas dominantemente de sedimentos paleocosteiros e litorâneos, situados na faixa de dobramentos Brasília ou quase borda com o paleocontinente Neoproterozoico/Cambriano da plataforma São Francisco (Tab. 2 e Fig. 1).

Geoformas O Vale comporta um grande número de formas, mas as principais, que correspondem a mais de $90 \%$ das variações do terreno, são: st, pd, rv, so, ch, pt, sa, krv, r, d, itrv, cr, str, sto, kerv, ptrv, pdr, pf, crv e sor (Fig. 2 e Tab. 3).

Solos Os solos mais comuns são os neossolos quartzarênicos, três tipos de cambissolos háplicos, 
Tabela 1 - Tipos de rochas ígneas, metamórficas e sedimentares com vista a integrar em escala regional de 1:5.000.000 a 1:500.000 as relações mais notáveis êrochas, geoformas, ordens de solos e aquíferos. Tratam-se de conjuntos abertos com amplas possibilidades de variações êrochas/solos ê, mas também com incompatibilidades de relações co-genéticas.

\begin{tabular}{|c|c|c|c|}
\hline $\begin{array}{l}\text { ROCHAS / grupos de rochas mais } \\
\text { comuns }\end{array}$ & $\begin{array}{l}\text { GEOFORMAS ou } \\
\text { MORFOTEMAS }\end{array}$ & $\begin{array}{c}\text { ORDENS de SOLOS } \\
\text { comuns* }\end{array}$ & $\begin{array}{c}\text { Tipos de aquíferos e de zonas de } \\
\text { recarga }\end{array}$ \\
\hline \multicolumn{4}{|l|}{ Ácidas: } \\
\hline \multirow[t]{2}{*}{$\begin{array}{l}1 \text { - alcali-granitos, adamalitos, } \\
\text { grandioritos } \\
2 \text { - alcali-microgranitos, micro- } \\
\text { adamalitos, microgranodioritos }\end{array}$} & $\begin{array}{l}1 \text { e } 2 \text { - (1) cordilheiras, (2) } \\
\text { encostas íngremes com matacões } \\
\text { de erosão esferoidal; (3) colinas } \\
\text { meia-laranja, (4) picos íngremes; }\end{array}$ & $\begin{array}{l}\text { Cambissolos. } \\
\text { Neossolos. }\end{array}$ & $\begin{array}{l}1 \text { e } 2 \text { - Aquíferos fraturados; em } \\
\text { saibros com ou sem esfoleação } \\
\text { esferoidal; aquíferos também dito } \\
\text { confinados. }\end{array}$ \\
\hline & $\begin{array}{l}\text { (5) vales encaixados; } \\
\text { (6) relevos íngremes com saibros e } \\
\text { saprolitos; (7) formas pão-de-açúcar; }\end{array}$ & Latossolos. & $\begin{array}{l}\text { Aquíferos rasos solos; aquíferos } \\
\text { de transição }\end{array}$ \\
\hline 3 - alcali-riolitos, riodacitos, dacitos & $\begin{array}{l}3 \text { - intrusivas locais sem } \\
\text { expressão regional. }\end{array}$ & & 3 - irrelevância \\
\hline \multicolumn{4}{|l|}{ Ultrabásicas } \\
\hline gabro / dolerito / basalto & plateaux de derrames. & $\begin{array}{l}\text { Nitossolos. } \\
\text { Latossolos } \\
\text { vermelhos. }\end{array}$ & $\begin{array}{l}\text { Aquíferos de vários tipos: basaltos } \\
\text { fortemente intemperizados } \\
\text { superficiais; fraturados; } \\
\text { confinados; co-distribuídos com } \\
\text { encaixantes clásticas. } \\
\text { Aquíferos rasos solos. }\end{array}$ \\
\hline
\end{tabular}

\begin{tabular}{l}
\hline Básicas \\
\hline Alcalinas e sienitos: \\
Super-saturados - 1 - qtz-sienitos / \\
qtz-microsienitos / qtz-traquitos \\
Saturados - 2 - sienitos / micro- \\
sienitos / traquitos \\
3 - traquitos \\
Sub-saturados - 4 - nefelina-sienitos \\
/nefelina micros-sienitos / leucitófiro \\
e fonolitos / lavas livres de leucitas e \\
feldspatos nefelínicos
\end{tabular}

\begin{tabular}{ll}
\hline Ultramafitos e Anortositos & idem (1), (2), (3), (4), (5), (6), (7) com \\
\hline $\begin{array}{l}\text { rochas sedimentares e para- } \\
\text { metamórficas } \\
\text { arenitos / margas / argilitos / }\end{array}$ & $\begin{array}{l}\text { plateaux; planícies de inundação; } \\
\text { deltas; planícies litorâneas; relevos } \\
\text { aplainados de bacias sedimentares } \\
\text { com diversos tipos de rochas } \\
\text { sedimentares não metaformizadas. } \\
\text { Relevos kársticos. } \\
\text { Colinas. }\end{array}$ \\
folhelhos / filitos & $\begin{array}{l}\text { Plateaux de lateritas e de cangas, } \\
\text { colinas, topos de peneplanos. } \\
\text { quartzitos }\end{array}$ \\
& Plateaux de quartzitos.
\end{tabular}

$1,2,3$, e 4 - encostas de cones
vulcânicos e crateras.
Diques.
Derrames.
Aquíferos centrados em circulação hídrica em paleovulcões e pegmatitos; confinados e caracterizados como água mineralizada.
Argissolos.

Neossolos.

\begin{abstract}
1 e 2 - Aquíferos fraturados; em saibros com ou sem esfoleação esferoidal; aquíferos também dito
\end{abstract}

Aquíferos rasos solos; aquíferos (n) 
Tabela 2 - Rochas e estratigrafia da bacia sedimentar de São Francisco no Vale do Paracatu apresentada na Fig. 1 (CETEC 1981)

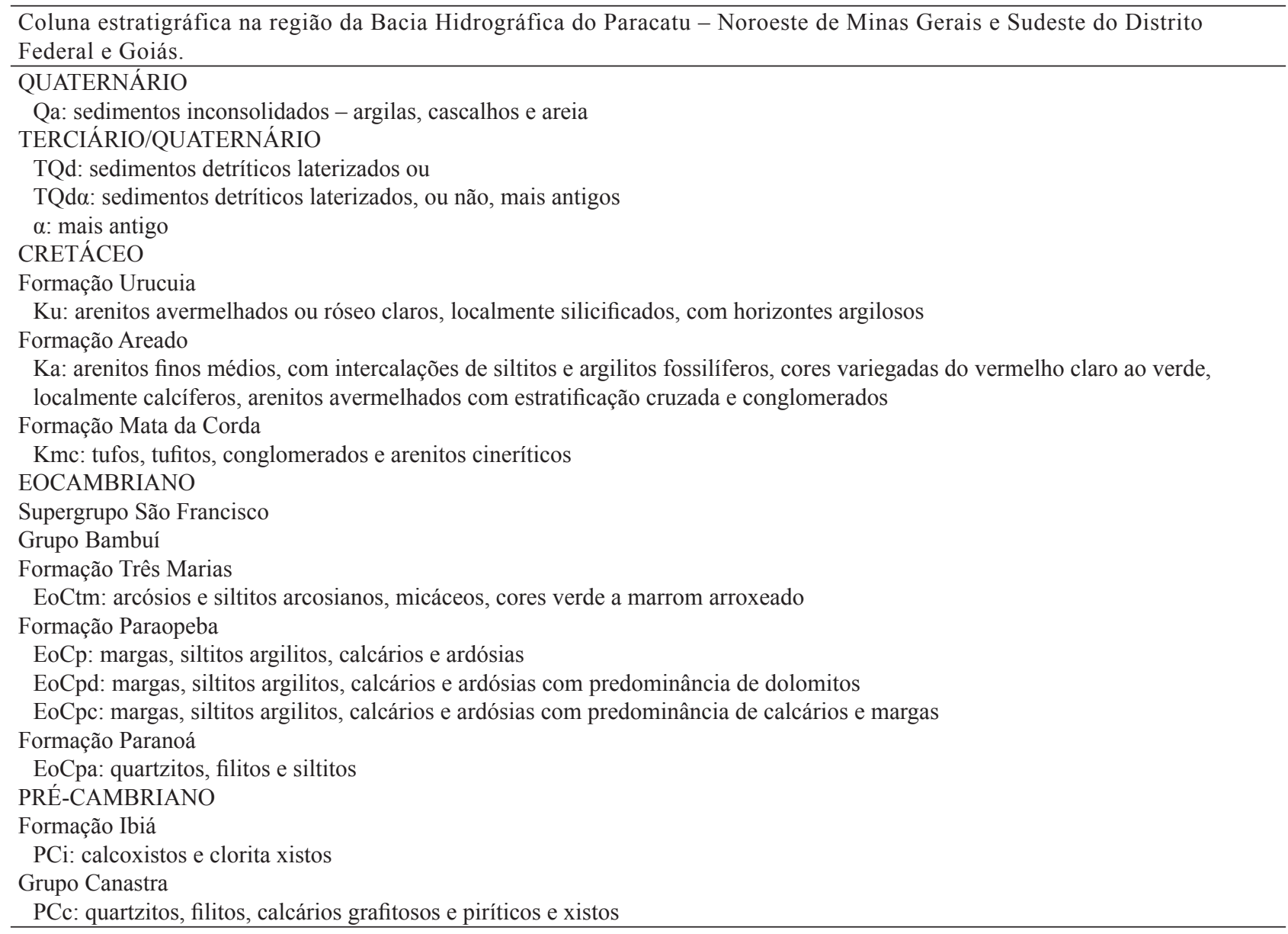

três de neossolos litólicos e cinco de latossolos vermelhos. Essa dominância é própria às rochas típicas do Vale (Fig. 3 e Tab. 4).

Rochas e geoformas As condições ambientais entre |rochas/geoformas| do Vale estão descritas pelas relações espaciais de associatividade na Tab. 5. As relações rochas e geoformas são consideradas de ambos os pontos de vista da geomorfologia estrutural e/ou climática.

Geoformas e solos As condições ambientais entre |geoformas/solos| do Vale podem ser descritas como favoráveis para diversos tipos de projetos agrícolas, florestais e de zoocultura. Os simples aspectos obtidos das cartas de aptidão agrícola, os tipos de plantas com suas exigências ambientais e as técnicas agrícolas disponíveis formam um quadro de opções que podem ser combinadas e descritas em quatro níveis de complexidade de condições, tais como: ultrafavoráveis, favoráveis, restritas e desfavoráveis. Esta classificação é própria do conceito de aptidão, porém precisa ser referida a outros fatores para que seja obtido um modelo mais amplo e representativo com: geotecnia do território da bacia hidrográfica; formas do terreno; tipos de solos; zonas de recarga; áreas geoambientais específicas; áreas florestais naturais específicas e microclimas, entre outros. Todos os temas devem ser considerados de modo integrado como determinantes para os quatro níveis de classificação citados. Isto não ocorre, todavia, para os mapas de aptidão de solos.

Obviamente, nem todas as espécies florestais nativas ou econômicas serão necessariamente adequadas, nem mesmo em condições ultrafavoráveis para plantio entre as associações de solos/rochas/geoformas. Isto é compreensível pelo fato de que a classificação de aptidão agrícola é principalmente articulável aos tipos de plantas/solos. Necessita-se articulá-la aos conceitos de ordenamento do território, fato não elaborado metodologicamente no Brasil. No Vale, as associações cogenéticas previstas na Tab. 1 são confirmadas, como observado nas Tabs. $6-7$. 


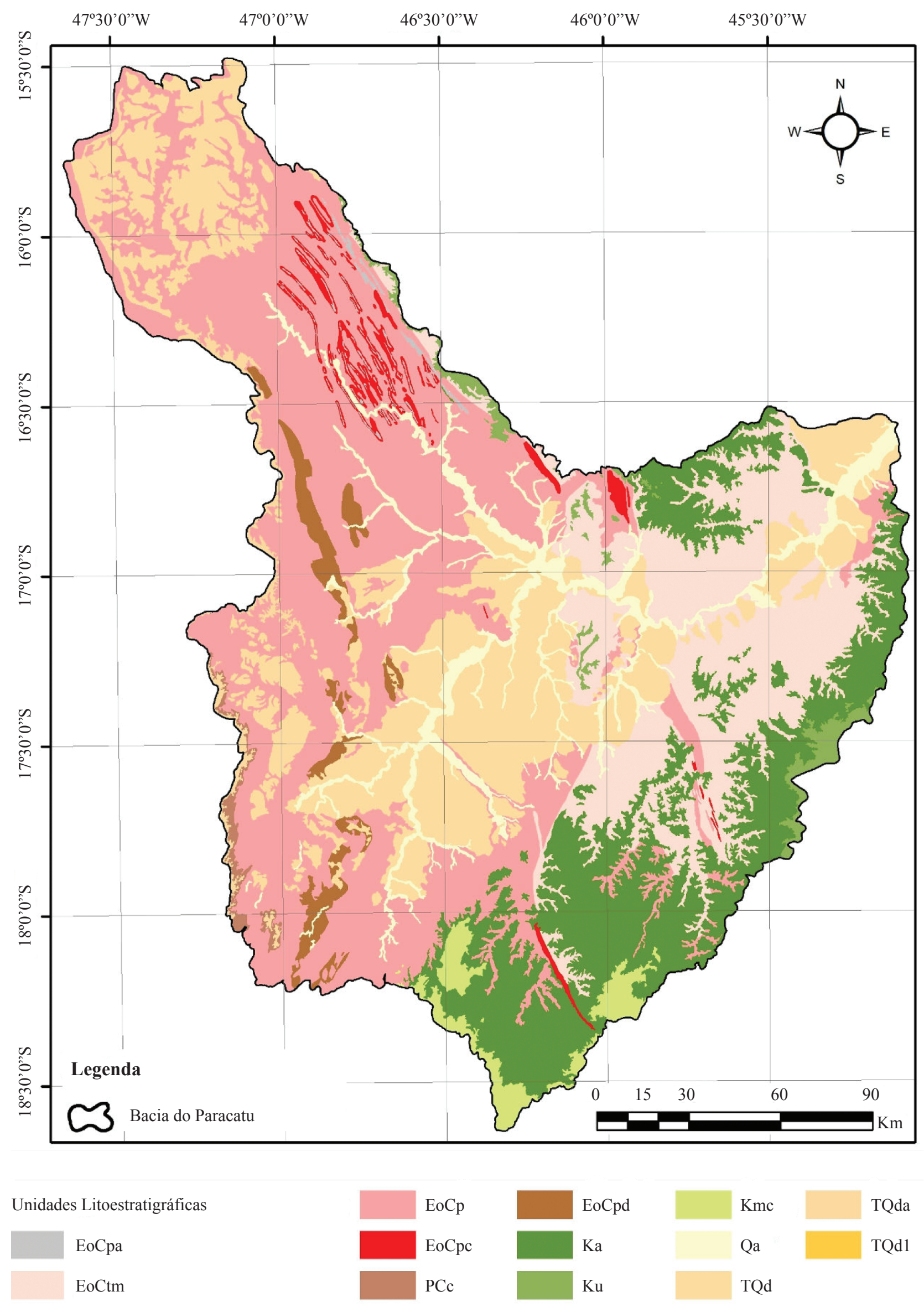

Figura 1-Carta litoestratigráfica da Bacia do Paracatu derivada e atualizada (escala original de 1:250.000; Plano Noroeste-CETEC 1981). 

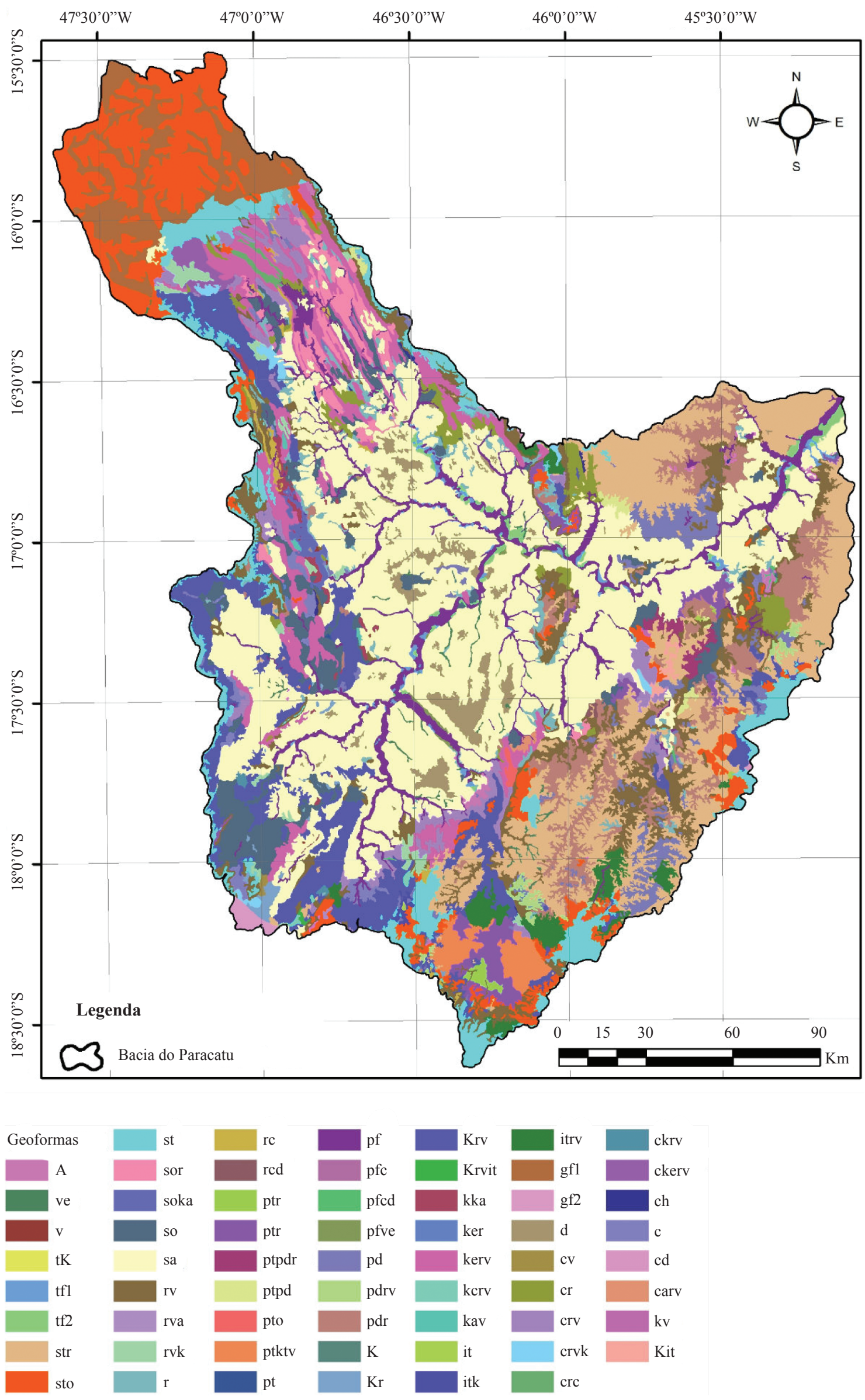

Figura 2 - Mapa geomorfológico do Paracatu, derivado e atualizado, disponivel na escala de 1:250.000 (CETEC 1981; Martins Jr. et al. 2006). 


\section{Geoformas}

1 st: superfície tabular de aplainamento em área de planalto, com depósitos de cobertura arenosos e argilosos e rede de drenagem

1 pouco densa, constituída por veredas. Ocorrência de áreas de infiltração acentuada sobre formações arenosas.

2 str: superfície tabular reelaborada - superfície de aplainamento em área de planalto, com depósitos de cobertura

2 predominantemente arenosos; rede de drenagem constituída por veredas em densidade relativamente elevada. pd: pedimentos - vertentes de declividade inferior a $8 \%$ elaboradas sobre rochas expostas ou cobertas por formações

3 superficiais que se integram com os depósitos colúvio-aluviais das superfícies de aplainamento. Áreas com escoamento superficial difuso.

4 r: vertentes ravinadas-dissecadas pelo escoamento fluvial concentrado, elaboradas predominantemente sobre rochas de baixa permeabilidade.

5 rv: vertentes ravinadas e vales encaixados - vertentes íngremes dissecadas pelo escoamento fluvial, concentrado em talvegues profundos.

6 ch: vertentes em chevron - vertentes litólicas ravinadas e/ou com vales encaixados, elaboradas sobre flancos de estruturas

6 dobradas. Áreas de escoamento superficial concentrado e difuso intenso.

7 cr: colinas com vertentes ravinadas.

8 crv: colinas com vertentes ravinadas e vales encaixados.

9 krv: cristas com vertentes ravinadas e vales encaixados.

10 kerv: cristas estruturais com vertentes ravinadas e vales encaixados.

pt: patamares rochosos - superfícies de aplainamento exumadas resultantes da atuação dos processos de erosão diferencial

11 entre formações cretácicas e rochas do Grupo Bambuí. Áreas de escoamento superficial difuso intenso, com ocorrências de cascalheiras remobilizadas.

12 sto: superfície de aplainamento degradada em área de planalto, com depósitos superficiais pouco espessos. Predomínio de escoamento superficial concentrado.

13 sor: superfície ondulada com vertentes ravinadas.

14 pdr: pedimentos ravinados.

15 ptrv: patamares rochosos com vertentes ravinadas e vales encaixados.

16 itrv: interflúvios tabulares com vertentes ravinadas e vales encaixados.

17 d: depressões rasas de fundo plano - áreas de má drenagem com rebaixamento pouco pronunciado, evoluídas sobre as 17 superfícies de aplainamento, com ocorrências de solos hidromórficos e concentração de lagoas temporárias.

Rochas e solos As condições ambientais entre |rochas/solos| do Vale podem ser descritas em conformidade com a Tab. 1. As relações dominantes de rochas e solos contínuas em áreas de maior extensão de rochas são: EoCp, EoCtm e TQd. Com relação aos solos, os dominantes são: $\mathrm{CXbd}_{1+2+3}, \mathrm{LVd}_{1+2+3+4}$, $\mathrm{RLd}_{1+2+4}, \mathrm{RQo}_{1+2+3+5}$, nos quais os valores índices numéricos indicam para cada quantidade um grande grupo de solos (Tabs. 1 e 8).

\section{Relações gerais entre rochas, geoformas e solos}

Em face dos dados apresentados, é possível iniciar a verificação das hipóteses levantadas na primeira parte do artigo como fundamentadas para a construção dos modelos das gestões geoambiental e econômica.

Em síntese, a evidência geral da Tab. 1 e o estudo de caso sobre o Vale do Paracatu permitem considerar, como demonstradas nas hipóteses 1 a 3, que ao serem resumidas são as seguintes proposições finais às hipóteses: as relações sistêmicas entre |rochas/geoformas/solos e as formações superficiais geotécnicas| são os aspectos irredutíveis fundamentais para modelos de gestão do uso da terra; a integração dessas relações sistêmicas aplicáveis a um sistema lógico interdisciplinar de auxílio à decisão deve assentar-se, de fato, segundo uma lógica que permita trabalhar com associatividades comuns e eventuais e anomalias associativas, amplamente evidentes dentro do Paracatu com $45.060 \mathrm{~km}^{2}$, que é uma superfície expressivamente grande para servir de área-exemplo; e está apropriada a lógica que caracteriza a possibilidade de esboçar as articulações entre as características e as complementaridades das várias escalas regionais às locais, para propriedades rurais e ao auxílio à decisão nesses diversos níveis.

A Tab. 9 apresenta e confirma as relações entre rochas, solos e geoformas para a Bacia do Rio Paracatu, conforme se propõe com as três hipóteses confirmadas para modelar os usos da terra, apoiados nas análises e confirmações que se apresentam neste artigo.

\section{Correlações entre escalas de representação carto-} gráfica e solos como aspectos críticos de auxílio à decisão A hipótese 4 aborda categorias de solos que se evidenciaram, de fato, ser das instâncias as mais fundamentais, para a elaboração das decisões de uso da terra em escalas do regional ao local. As evidências relacionais das Tabs. $6-9$ permitem essa perspectiva integrada da importância dos solos, como os mais diversificados sistemas em função das rochas, essas em menor quantidade de variedades, seguida das geoformas em maior número, e os solos ainda número 


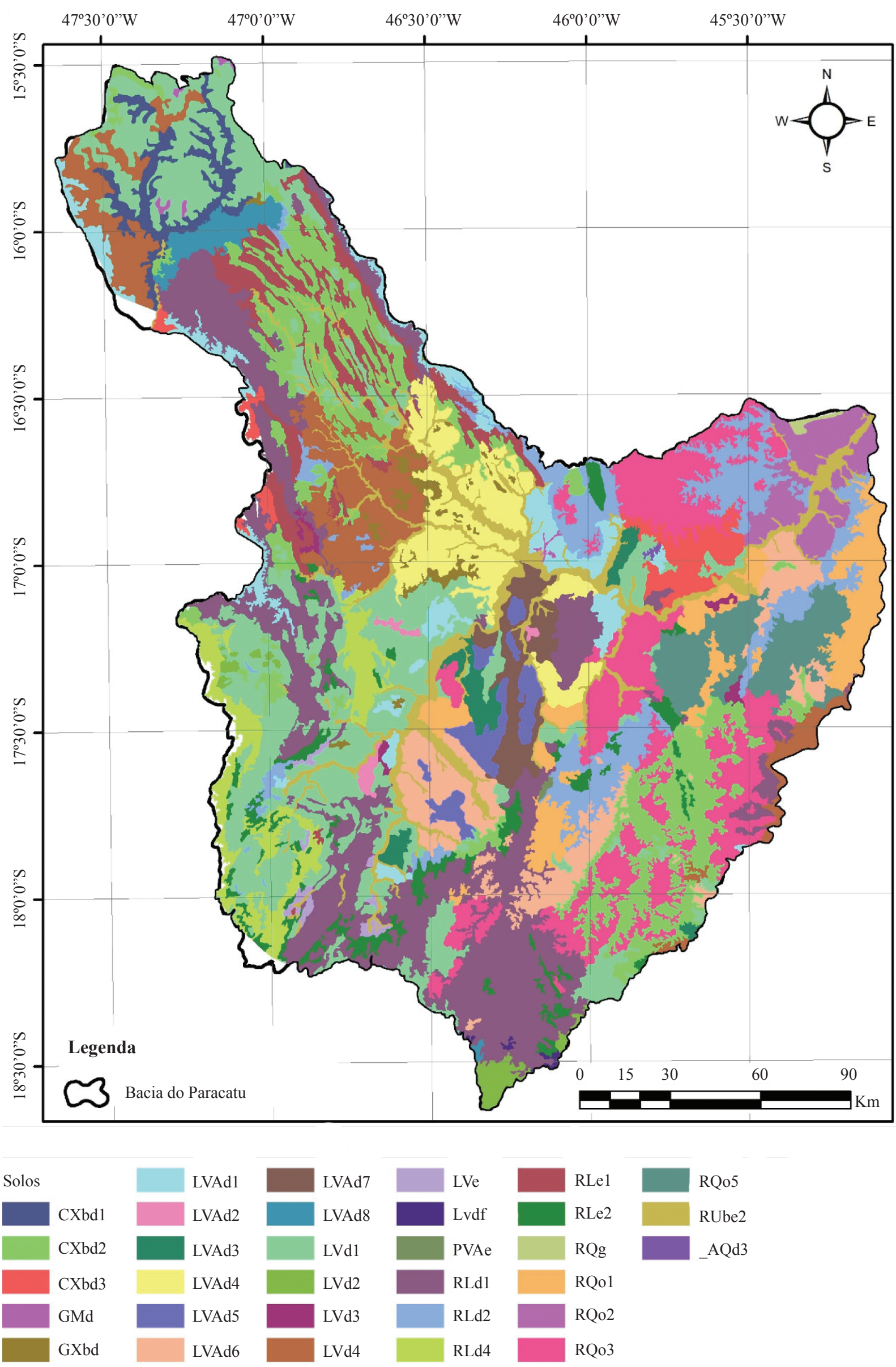

Figura 3-Mapa de solos do Paracatu com 40 tipos mapeados disponivel na escala de 1:250.000(CETEC 1981), atualizado em 2004 para o Sistema Brasileiro. 
Tabela 4 - Principais solos do Vale do Paracatu segundo a classificação brasileira, de 1995 (Marques et al. 2004), em número de 14, entre 40 tipos existentes

Solos

1 LVd1: latossolos vermelhos distróficos típicos argilosos A moderado álicos fase cerrado relevo plano e suave ondulado.

2 RQo3: neossolos quartzarênicos órticos típicos A fraco e moderado álicos + latossolos vermelho amarelos distrópicos típicos

2 textura média A moderado álicos fase cerrado relevo plano e suave ondulado.

$3 \mathrm{CXbd}$ : cambissolos háplicos Tb; distróficos típicos argilosos textura média A moderado álicos fase campo cerrado + latossolos vermelho amarelos; distróficos típicos argilosos A moderado álicos fase cerrado fase relevo plano e suave ondulado.

4 RLd1: neossolos litólicos distróficos típicos textura indiscriminada A fraco e moderado álicos fase campo cerrado relevo forte ondulado.

5 RQg: neossolos quartzarênicos hidromórficos típicos A fraco e moderado álicos fase campo cerrado relevo plano.

6 CXbd2: cambissolos háplicos Tb distróficos típicos argilosos textura média A moderado álicos + neossolos litólicos distróficos

6 textura indiscriminada A fraco e moderado álicos fase campo cerrado relevo ondulado.

$7 \mathrm{CXbd}$ 2: cambissolos háplicos Tb distróficos típicos argilosos textura média A moderado álicos + neossolos litólicos distróficos textura indiscriminada A fraco e moderado álicos fase campo cerrado relevo ondulado.

8 RLd1: neossolos litólicos distróficos típicos textura indiscriminada A fraco e moderado álicos fase campo cerrado relevo forte ondulado. RLe1: neossolos litólicos eutróficos chernossólicos + neossolos litólicos eutróficos típicos A moderados ambos textura

9 indiscriminada fase floresta caducifólia relevo montanhoso + neossolos litólicos distróficos típicos A moderado, textura indiscriminada fase campo cerrado relevo montanhoso + afloramentos de rochas.

10 LVd1: latossolos vermelhos distróficos típicos argilosos A moderado álicos fase cerrado relevo plano e suave ondulado.

11 CXbd2: cambissolos háplicos Tb distróficos típicos argilosos textura média A moderado álicos + neossolos litólicos distróficos textura indiscriminada $\mathrm{A}$ fraco e moderado álicos fase campo cerrado relevo ondulado.

12 RLd2: neossolos litólicos distróficos típicos textura indiscriminada A fraco e moderado álicos + cambissolos háplicos Tb

distróficos típicos argiloso e textura média A moderado álicos fase campo cerrado relevo ondulado e forte ondulado.

13 RLd1: neossolos litólicos distróficos típicos textura indiscriminada A fraco e moderado álicos fase campo cerrado relevo forte ondulado.

14 LVAd5: latossolos vermelho amarelos distróficos plínticos argilosos A moderado álicos + neossolos quartzarênicos órticos

14 típicos A fraco e moderado álicos fase campo cerrado relevo plano e suave ondulado.

superior. Todavia, a dominância de solos segue de perto as rochas e geoformas, com ocorrência de solos mais raros em áreas restritas, o que permite identificar as "associatividades comuns" da conclusão sobre a hipótese 2 como "associatividades dominantes". Desta forma, pode-se conceber que a tipologia de solos seja o aspecto mais sensível para o auxílio à decisão geoambiental de gestão do uso da terra, sem exclusão dos outros geossistemas, que analisados podem informar o que as cartas pedológica, de aptidão de solos e agroclimatológica não podem informar. Aquelas informações são de outras categorias do que essas.

Portanto, dentro de uma perspectiva de arquitetura de conhecimentos (Martins Jr. et al. 2006, Martins Jr. \& Vasconcelos 2008) de decisão do regional ao local, deve-se tratar como condição fundamental as associações entre |rochas, geoformas e solos| que sejam, primeiramente, lógicas e cogenéticas, enquanto outras decorrem de transformações geotécnicas, geoquímicas e edafoquímicas mais específicas. Nessas, os microorganismos, os sistemas radiculares e o húmus têm mais importância na gênese e tipificação de solos, afastandoos de relações clássicas cogenéticas |rochas-solos|, mas no contexto dessas relações as categorias de solos são das primeiras e mais fundamentais instâncias para a aproximação em escalas do regional ao local.

Em segundo plano, para o planejamento do uso da terra para agricultura, silvicultura, pastagens, áreas de mitigação, produção de energia com minicentrais hidroelétricas a fio d'água, produção de biomassa para energia e industrialização rural, são necessários conhecimentos sobre as relações geotécnicas, que exigem a produção de cartas geotécnicas, com estudo de distribuição espacial de atributos físicos de rochas, solos e formações superficiais. São necessárias também as várias cartas de pluviosidade |chuva anual, do período chuvoso e do período seco, coeficiente de variação anual das chuvas, número de dias de chuvas anual e máxima anual, coeficiente de variação do período chuvoso, número de dias de chuvas no período chuvoso, chuva máxima no período chuvoso e chuvas de janeiro a dezembro, já que a chuva é entre os agentes naturais o mais ativo em regiões tropicais. Por certo, que os ventos e o tempo de foto-periodicidade são aspectos não negligenciáveis. Com essas informações, completa-se o sistema básico de informações para serem iniciados os zoneamentos ecológicos, econômicos e ecológico-econômicos de bacias hidrográficas (Martins Jr. et al. 2008, Martins Jr. \& Ferreira 2009, Martins Jr. et al. 2010).

\section{Sobre a obtenção das áreas totais: nativa, plantada e} passível de recuperação Considerando-se, portanto, as relações evidenciadas sobre rochas/geoformas/solos, fica evidente que essas categorias de entidades geológicas são a base para a decisão e, portanto, o passo seguinte, ainda dentro da primeira etapa, implicará em se programar 
Tabela 5 - Relações espaciais entre rochas e geoformas no Vale doParacatu em $\mathrm{km}^{2}$

\begin{tabular}{|c|c|c|c|c|c|c|c|c|c|c|c|c|}
\hline Rochas / Geo-formas & EoCp & EoCpa & EoCpc & EoCpd & EoCtm & $\mathrm{Ka}$ & $\mathrm{Kmc}$ & $\mathrm{Ku}$ & $\mathrm{PCc}$ & $\mathrm{Qa}$ & TQd & TQda \\
\hline $\mathrm{A}$ & 78,16 & & & & 36,54 & 3,99 & 0,43 & & & 1,77 & 5,10 & \\
\hline Kit & 3,70 & & & & 35,81 & 12,75 & & & & & & \\
\hline $\mathrm{Kv}$ & & & & & 5,15 & 0,38 & & & & & & \\
\hline $\mathrm{c}$ & 182,96 & & 2,64 & 5,91 & 11,25 & & & & 3,68 & 6,98 & 1,55 & 0,19 \\
\hline carv & 24,89 & & & & 0,28 & & & & & 1,37 & & \\
\hline $\mathrm{cd}$ & & & & & & & & & & 0,48 & & \\
\hline $\mathrm{ch}$ & 17,06 & 2,33 & 9,38 & & 1,45 & 0,04 & & & & 0,94 & & \\
\hline ckcrv & 152,25 & & & & & & & & & & 1,27 & \\
\hline ckrv & 23,52 & & & & & & & & & & & \\
\hline $\mathrm{cr}$ & 344,05 & 6,79 & 64,10 & 0,52 & 153,19 & 11,60 & & 3,17 & & 5,31 & 0,76 & \\
\hline cre & 53,30 & 1,13 & 11,08 & & & & & & & & & \\
\hline crv & 659,30 & 10,97 & 38,46 & 2,05 & 133,13 & 18,89 & 0,01 & 1,57 & 2,59 & 3,57 & 1,96 & 0,40 \\
\hline crvk & 122,51 & & & & 4,15 & & & & & & & \\
\hline $\mathrm{cv}$ & 18,51 & & & & & & & & & & & \\
\hline $\mathrm{d}$ & 218,93 & & & & 1,03 & & & 3,67 & & 6,75 & 557,36 & \\
\hline gf1 & $1.057,94$ & 0,02 & 4,59 & & 0,00 & & & & & & 529,48 & \\
\hline gf2 & 80,11 & & & 5,06 & 2,18 & 0,96 & & 3,54 & & & & \\
\hline it & 0,53 & & & & 5,87 & 7,46 & & 0,44 & & & & \\
\hline itq & 7,42 & & & & 0,00 & 21,32 & 3,28 & 0,00 & & & & \\
\hline itrv & 81,77 & & 11,10 & & 78,19 & 385,29 & 13,76 & 4,61 & & & & \\
\hline $\mathrm{k}$ & 4,42 & & 1,02 & & & 1,06 & & & & 0,77 & & \\
\hline kav & 2,72 & & & 19,06 & & & & & & & & \\
\hline kcrv & 14,68 & & & 3,63 & & 3,12 & & & & & & \\
\hline ker & 4,63 & & & & & & & & & & 0,19 & \\
\hline kerv & $1.470,60$ & 90,99 & 238,12 & 103,78 & 37,92 & 7,94 & 0,08 & 7,28 & & 10,44 & 7,92 & 3,85 \\
\hline kka & 14,37 & & & 123,76 & & & & & & & & \\
\hline $\mathrm{kr}$ & 80,33 & & 0,22 & 8,95 & & 2,65 & 1,22 & & 1,30 & 0,07 & 2,61 & 0,94 \\
\hline krv & $2.302,53$ & & 9,46 & 37,42 & 64,48 & 287,83 & 30,88 & 13,30 & 113,41 & 0,57 & 24,65 & 45,49 \\
\hline krvit & 6,08 & & & 3,26 & & & & & & & & \\
\hline $\mathrm{pd}$ & 77,53 & 2,20 & 11,11 & 0,26 & 484,96 & 279,39 & 5,80 & 22,60 & 3,81 & 4,37 & 23,98 & 0,81 \\
\hline $\mathrm{pdr}$ & 133,26 & & & 2,73 & $1.269,03$ & 453,74 & 0,98 & 10,52 & & 2,91 & 3,99 & 1,43 \\
\hline pdrv & 0,06 & & 3,65 & 0,00 & 62,92 & 60,76 & 2,93 & & & & & \\
\hline $\mathrm{pf}$ & 320,80 & 2,89 & 15,49 & 11,09 & 104,66 & 4,11 & & & 0,72 & $1.404,49$ & 80,65 & 0,19 \\
\hline $\mathrm{pfc}$ & 0,38 & & & & & & & & & & & \\
\hline pfed & 2,65 & & & & 13,31 & & & 2,48 & & 0,04 & & \\
\hline pfve & 16,66 & & & & & & & & & 14,06 & 5,74 & \\
\hline $\mathrm{pt}$ & 5,06 & & & & & & & & & & 1,07 & \\
\hline ptkrv & 15,17 & & 0,75 & & & 378,55 & 3,86 & & & & & \\
\hline pto & 32,98 & & & & 0,00 & & & & & & & \\
\hline ptpd & 1,34 & & & & 89,80 & 4,09 & & & & 0,52 & 0,39 & \\
\hline ptpdr & & & & & 115,41 & 14,60 & & & & 0,00 & & \\
\hline ptr & 2,45 & & & & & 53,24 & & & & 0,69 & & \\
\hline ptrv & 60,41 & & & & 211,13 & 271,39 & & 3,09 & 3,94 & & 0,03 & 2,64 \\
\hline $\mathrm{r}$ & 384,15 & 8,36 & 24,41 & 24,38 & 142,97 & 16,43 & 0,18 & 7,52 & 1,65 & 19,29 & 9,56 & \\
\hline $\mathrm{rc}$ & 72,75 & 0,76 & 3,78 & 23,51 & & 3,72 & 18,66 & & & 9,10 & & \\
\hline red & & & & & 13,51 & & & & & & & \\
\hline rv & 820,91 & 5,98 & 32,04 & 13,99 & $1.327,56$ & 388,78 & 39,98 & 21,67 & 31,07 & 4,24 & 17,85 & \\
\hline rva & 6,50 & & & & & & & & & & & \\
\hline rvk & 231,66 & 1,32 & 1,44 & 3,75 & 0,30 & 12,24 & 0,16 & & 4,95 & 0,32 & 0,50 & \\
\hline as & $3.895,74$ & 9,98 & 37,22 & 283,57 & $1.449,84$ & 52,41 & & & 0,93 & 419,47 & & \\
\hline so & $1.063,29$ & 9,85 & 31,82 & 106,27 & 221,43 & 0,01 & & & 6,03 & 23,67 & & \\
\hline soka & 15,28 & & & 79,07 & & & & & & 15,44 & & \\
\hline sor & 470,34 & 22,42 & 75,29 & & 20,56 & & & & & 17,05 & & \\
\hline st & 259,72 & 1,48 & 9,19 & 0,62 & 23,17 & 103,79 & 542,20 & 362,76 & 38,04 & & 317,45 & \\
\hline sto & 763,51 & 1,53 & 20,76 & 1,13 & 105,86 & 558,04 & 74,99 & 39,97 & & & 14,31 & \\
\hline str & 110,39 & & 8,34 & 11,96 & 584,72 & $3.523,96$ & 12,04 & 46,83 & & 6,78 & & \\
\hline $\mathrm{tf1}$ & 6,92 & & & & 1,32 & 0,15 & & & & 141,29 & & \\
\hline $\mathrm{tf} 2$ & 7,31 & & & & 2,81 & & & & & 168,26 & & \\
\hline tk & & & & & & 1,22 & & & & & & \\
\hline $\mathrm{v}$ & 1,00 & & & 5,21 & & & & & & 0,14 & & \\
\hline ve & 14,59 & & & & 8,28 & 26,82 & & & & 38,19 & & \\
\hline Total & $15.820,08$ & 179,00 & 665,48 & 880,97 & $6.824,14$ & $6.972,73$ & 751,44 & 555,00 & 212,11 & $2.326,33$ & 407,80 & \\
\hline
\end{tabular}


Tabela 6a-Relações espaciais entre geoformas (linhas) e solos (colunas) em km²

\begin{tabular}{|c|c|c|c|c|c|c|c|c|c|c|}
\hline Solos/geoformas & AQd3 & CXbd1 & CXbd2 & CXbd3 & GMd & GXbd & LVAd1 & LVAd2 & LVAd3 & LVAd4 \\
\hline st & & 3,52 & 17,47 & 49,78 & & 1,28 & 350,73 & & & \\
\hline $\mathrm{pd}$ & & & 190,26 & 279,09 & & & 14,32 & & 2,59 & 19,44 \\
\hline rv & & & 472,71 & 21,39 & & & 3,14 & & & 5,47 \\
\hline so & & & 309,45 & 28,10 & & & 15,86 & & & 34,59 \\
\hline $\mathrm{sa}$ & 0,05 & & 215,01 & 168,83 & 3,36 & 72,43 & 664,50 & 102,90 & 371,71 & 1546,83 \\
\hline krv & & & 119,38 & & & & 0,43 & 0,06 & & \\
\hline $\mathrm{r}$ & & & 119,56 & & & & 0,06 & & 0,63 & 26,16 \\
\hline $\mathrm{d}$ & & & & & 3,97 & 219,48 & 23,54 & 9,13 & 13,25 & 42,34 \\
\hline itrv & & & 191,72 & & & & & & 4,33 & \\
\hline $\mathrm{cr}$ & & & 224,89 & & & & 6,44 & & & 12,15 \\
\hline str & 14,58 & & 291,43 & 9,14 & & & 4,14 & & 15,94 & \\
\hline sto & & 299,40 & 115,13 & 99,15 & 31,97 & 1,43 & 102,01 & & & \\
\hline kerv & & & 15,78 & & & & 0,08 & & & 0,07 \\
\hline ptrv & & & 18,47 & & & & & & & \\
\hline $\mathrm{pdr}$ & & & 361,10 & 4,09 & & & 5,54 & & & \\
\hline $\mathrm{pf}$ & & & 122,51 & 4,85 & 4,36 & & 9,41 & 1,12 & 5,20 & 16,88 \\
\hline crv & & & 390,96 & & & & 0,03 & & & \\
\hline sor & & & 523,52 & & & & & & & 0,42 \\
\hline Solos/geoformas & LVAd5 & LVAd6 & LVAd7 & LVAd8 & LVd1 & $\mathrm{LVd} 2$ & LVd3 & LVd4 & Lvdf & LVe \\
\hline st & & 0,56 & & 348,00 & 413,88 & 129,21 & & 189,76 & 2,90 & \\
\hline $\mathrm{pd}$ & & 24,17 & & 0,05 & 54,45 & & 2,52 & 32,91 & & \\
\hline rv & & 71,98 & & 3,75 & 37,40 & 25,25 & 0,75 & 2,94 & 6,47 & 1,05 \\
\hline so & & 15,70 & 19,21 & & 692,35 & 0,07 & 27,50 & 20,19 & & 0,02 \\
\hline $\mathrm{sa}$ & 225,91 & 878,95 & 649,76 & & 3061,80 & 68,89 & 48,28 & 1176,43 & & 101,96 \\
\hline krv & & 28,98 & & 0,91 & 31,34 & 0,84 & & 1,31 & 3,61 & 1,48 \\
\hline $\mathrm{r}$ & & 18,62 & 1,88 & 1,85 & 17,55 & & 0,23 & 16,27 & 0,29 & \\
\hline $\mathrm{d}$ & 345,33 & 10,56 & 16,91 & & 42,05 & & & 11,25 & & \\
\hline itrv & 1,94 & & & & 8,08 & 26,92 & & 0,30 & 0,40 & \\
\hline $\mathrm{cr}$ & & & 0,12 & & 0,09 & & & 1,58 & & \\
\hline str & & 481,42 & & & 84,77 & 0,06 & & 52,59 & 2,64 & \\
\hline sto & & 31,40 & & 42,48 & 1113,03 & 9,87 & & 363,55 & 14,25 & \\
\hline kerv & & 1,06 & 1,10 & 0,12 & 8,23 & & & 56,51 & & 2,17 \\
\hline ptrv & & 0,17 & & & & & 0,66 & & 0,18 & \\
\hline $\mathrm{pdr}$ & & 44,06 & 3,91 & & 8,77 & & & 4,05 & & \\
\hline $\mathrm{pf}$ & 2,23 & 16,62 & 24,22 & & 70,75 & 0,09 & 0,86 & 3,87 & & 5,52 \\
\hline crv & & 2,94 & & & 7,87 & & & & 0,01 & \\
\hline sor & & 0,49 & & & 21,76 & & & & & \\
\hline
\end{tabular}

\begin{tabular}{|c|c|c|c|c|c|c|c|c|c|c|c|c|}
\hline $\begin{array}{l}\text { Solos/ } \\
\text { geoformas }\end{array}$ & PVAe & RLd1 & RLd2 & RLd4 & RLe1 & RLe2 & RQg & RQo1 & RQo2 & RQo3 & RQo5 & RUbe2 \\
\hline st & & 52,73 & 8,17 & 29,29 & 15,14 & 1,23 & & 43,29 & & 38,87 & 3,73 & \\
\hline $\mathrm{pd}$ & & 40,72 & 38,12 & 17,59 & 10,27 & 3,68 & & 21,41 & & 135,88 & 27,67 & \\
\hline rv & 2,41 & 864,94 & 684,34 & 53,60 & 32,33 & 81,58 & & & & & & \\
\hline so & & 129,43 & 51,05 & 93,17 & 18,88 & 72,01 & & & 12,07 & 0,75 & 63,10 & 9,44 \\
\hline $\mathrm{sa}$ & & 252,00 & 137,15 & 71,62 & 12,15 & 126,87 & & 482,54 & 547,18 & 741,65 & 69,22 & 253,14 \\
\hline krv & & 1820,50 & 74,44 & 628,61 & 3,12 & 155,95 & & 1,69 & & 18,31 & 23,28 & 7,04 \\
\hline $\mathrm{r}$ & 9,67 & 151,49 & 101,63 & 18,73 & 79,17 & 5,36 & & 0,53 & & 23,42 & 13,75 & 30,44 \\
\hline $\mathrm{d}$ & & & 2,27 & & & & & 11,45 & 2,22 & 12,58 & & 21,32 \\
\hline itrv & & 260,14 & 20,11 & & & 26,70 & & & & 28,26 & 4,24 & \\
\hline $\mathrm{cr}$ & & 61,09 & 89,37 & 2,34 & 16,19 & 65,06 & & 0,48 & & & 109,33 & 0,34 \\
\hline str & & 142,86 & 96,66 & 0,00 & & 13,55 & 36,68 & 818,73 & 334,20 & 2092,98 & 161,70 & 1,30 \\
\hline sto & & 243,98 & 10,93 & & 3,83 & 24,37 & & 76,18 & & 222,72 & 72,64 & 6,47 \\
\hline kerv & 5,60 & 379,22 & 48,30 & 96,56 & 1263,16 & 92,85 & & 5,23 & & & & 2,77 \\
\hline ptrv & & 319,24 & 106,14 & 5,78 & & 6,19 & & 0,42 & & 6,20 & 89,07 & \\
\hline pdr & & 99,53 & 710,08 & 11,12 & & 10,98 & & 114,24 & 8,57 & 209,51 & 283,03 & \\
\hline $\mathrm{pf}$ & & 26,09 & 29,55 & 6,91 & 21,32 & 5,97 & & 7,52 & 0,67 & 35,87 & 21,53 & 1497,98 \\
\hline crv & & 202,12 & 51,42 & 29,31 & 0,83 & 105,08 & & 3,95 & & 13,31 & 58,89 & 1,80 \\
\hline sor & & 15,10 & 19,70 & & 0,67 & 0,15 & & & & & & 23,84 \\
\hline
\end{tabular}


Tabela 7 - Relações em áreas entre principais geoformas e solos superpostos no Vale do Paracatu

\begin{tabular}{|c|c|c|}
\hline & Geoformas & Solos principais sobre geoformas \\
\hline 1 & st: superfície tabular de aplainamento em área de planalto & LVd1: latossolos vermelhos distróficos \\
\hline 2 & $\begin{array}{l}\text { str: superfície tabular reelaborada - superfície de aplainamento } \\
\text { em área de planalto }\end{array}$ & $\begin{array}{l}\text { RQo3: neossolos quartzarênicos + latossolos vermelho- } \\
\text { amarelados distróficos }\end{array}$ \\
\hline 3 & pd: pedimentos - vertentes de declividade inferior a oito & $\begin{array}{l}\text { CXbd3: cambissolos háplicos Tb distróficos + latossolos } \\
\text { vermelho-amarelados distróficos }\end{array}$ \\
\hline 4 & r: vertentes ravinadas & RLd1: neossolos litólicos distróficos \\
\hline 5 & rv: vertentes ravinadas e vales encaixados & RLd1: neossolos litólicos distróficos \\
\hline 6 & $\begin{array}{l}\text { ch: vertentes em chevron - vertentes litólicas ravinadas e/ou } \\
\text { com vales encaixados }\end{array}$ & RQg: neossolos quartzarênicos hidromórficos \\
\hline 7 & cr: colinas com vertentes ravinadas & $\begin{array}{l}\text { CXbd2: cambissolos háplicos Tb distróficos + neossolos } \\
\text { litólicos distróficos }\end{array}$ \\
\hline 8 & crv: colinas com vertentes ravinadas e vales encaixados & $\begin{array}{l}\text { CXbd2: cambissolos háplicos Tb distróficos + neossolos } \\
\text { litólicos distróficos }\end{array}$ \\
\hline 9 & krv: cristas com vertentes ravinadas e vales encaixados & RLd1: neossolos litólicos distróficos \\
\hline 10 & kerv: cristas estruturais com vertentes ravinadas e vales encaixados & $\begin{array}{l}\text { RLe1: neossolos litólicos eutróficos + neossolos litólicos eutróficos } \\
+ \text { neossolos litólicos distróficos }+ \text { afloramentos de rochas }\end{array}$ \\
\hline 11 & sto: superfície de aplainamento degradada & LVd1: latossolos vermelhos distróficos \\
\hline 12 & sor: superfície ondulada com vertentes ravinadas & $\begin{array}{l}\text { CXbd2: cambissolos háplicos Tb distróficos + neossolos } \\
\text { litólicos distróficos }\end{array}$ \\
\hline 13 & pdr: pedimentos ravinados & $\begin{array}{l}\text { RLd2: neossolos litólicos distróficos + cambissolos háplicos } \\
\text { Tb distróficos }\end{array}$ \\
\hline 14 & ptrv: patamares rochosos com vertentes ravinadas e vales encaixados & RLd1: neossolos litólicos distróficos \\
\hline & d: depressões rasas de fundo plano & $\begin{array}{l}\text { LVAd5: latossolos vermelho-amarelados distróficos + } \\
\text { neossolos quartzarênicos }\end{array}$ \\
\hline
\end{tabular}

as áreas de: conservação; preservação; mitigação e utilização antrópica, em que as questões de desmatamento, florestamento, reflorestamento, mitigação com obras de engenharia e produção agrícola, de silvicultura e pastagens poderão ser planejadas e articuladas sobre os mapas de solos ou sobre os de aptidão agrícola, de modo a que todas as restrições e multiusos não explicitáveis nesses mesmos mapas possam ser integrados em uma nova categoria de mapas dos zoneamentos citados e na cartografia de desenho de uso optimal do território-DUOT (Martins Jr. et al. 2006, 2008, 2009, 2010).

Para tanto, planejar o uso do território implica em colocar em perspectiva as áreas potenciais, em uso, degradadas, com necessidades específicas de técnicas de conservação ambiental, bem como aquelas estritas para preservação ambiental. Por isso, outro grupo de cartografias será necessário a partir das informações que se devem agregar, segundo a equação lógica (Eq. 1), a saber, planejar o 'ordenamento regional do território' para se estimar a área total replantável, garantidos os interesses geoecológicos entre rochas, geoformas, solos, áreas agrícolas e agriculturáveis e os interesses econômicos, seguindo a Eq. 1:

$\mathrm{S} \mathrm{S}_{\mathrm{F}}=\mathrm{S}_{\mathrm{BH}} \pm \mathrm{S}_{\mathrm{Rs}}-\mathrm{S}_{\mathrm{Gi}}-\mathrm{S}_{\mathrm{Si}}-\mathrm{S}_{\mathrm{CVr}} \pm \mathrm{S}_{\mathrm{Ad}} \pm \mathrm{S}_{\mathrm{Av}} \pm \mathrm{S}_{\mathrm{P}}-\mathrm{S}_{\mathrm{U}^{-}}$

$-\mathrm{S}_{\mathrm{OE}}-\mathrm{S}_{\mathrm{Ca}}$

onde cada membro deve ser desenvolvido segundo a(s) questão(ões) em pauta:
$\mathrm{S} \mathrm{S}_{\mathrm{F}}$ : área total disponível para reflorestamento e/ou florestamento, em macrovisão;

$\mathrm{S}_{\mathrm{BH}}$ : área total da bacia;

$\mathrm{S}_{\mathrm{Rs}}$ : área de rochas com formações superficiais sensíveis ou metaestáveis;

$\mathrm{S}_{\mathrm{Gi}}$ : áreas de geoformas mais ou menos inadequadas;

$\mathrm{S}_{\mathrm{Si}}$ : áreas de solos mais ou menos inadequados;

$\mathrm{S}_{\mathrm{CVr}}$ : áreas de coberturas vegetal remanescentes e áreas legais;

$\mathrm{S}_{\mathrm{Ad}}$ : áreas com agricultura;

$\mathrm{S}_{\mathrm{Av}}$ : áreas agricultáveis;

$\mathrm{S}_{\mathrm{P}}$ : áreas de pastagens;

$\mathrm{S}_{\mathrm{U}}$ : áreas urbanas e urbanizáveis;

$\mathrm{S}_{\mathrm{OE}}$ : áreas de obras de engenharia;

$\mathrm{S}_{\mathrm{Ca}}$ : áreas de corpos d'água;

土: poder utilizar, ou não, para finalidades florestais.

"A questão econômica também se apoia sobre as questões geoecológicas ou de adequação $1 / 2$ planta/água/solos/climas-microclimas $1 / 2$ de modo que as relações específicas entre produção de biomassa para energia - BE - e biomassa para alimentação - BA se colocam de modo crítico no País, daí demandar estudos detalhados das bacias para o mapa de usabilidade como um instrumento de auxílio à decisão a fazer parte do sistema de arquitetura de conhecimentos (www.cetec.br/sisorci) e dos sistemas inteligentes de auxílio à decisão (família SisDec de sistemas)" 
Tabela 8 - Relações espaciais entre rochas e solos no Vale do Paracatu-km2. Em negrito, estão marcadas as interseções das rochas mais típicas encontradas sob cada tipo de solo (análise por linha). Sublinhado, estão marcadas as intercessões dos solos mais típicos encontrados sobre cada tipo de rocha (análise por coluna).

\begin{tabular}{|c|c|c|c|c|c|c|c|c|c|c|c|c|c|}
\hline & $\begin{array}{c}\text { Rochas/ } \\
\text { solos }\end{array}$ & EoCp & EoCpa & EoCpc & EoCpd & EoCtm & $\mathrm{Ka}$ & $\mathrm{Kmc}$ & $\mathrm{Ku}$ & PCc & Qa & TQd & TQda \\
\hline 1 & CXbd1 & 370,971 & & & & & & & & & & 360,562 & \\
\hline 2 & CXbd2 & $2.006,303$ & 49,562 & 193,792 & 52,785 & 777,102 & 837,709 & 15,084 & 20,077 & & 37,101 & 70,778 & \\
\hline 3 & CXbd3 & 121,656 & & & 0,515 & 535,551 & 18,757 & & & & 0,832 & 8,759 & 23,735 \\
\hline 4 & GMd & 5,797 & & & & 3,693 & & & & & 10,703 & 33,508 & \\
\hline 5 & GXbd & 218,775 & & & & 0,026 & & & 1,259 & & 0,837 & 85,315 & \\
\hline 6 & LVAd1 & 229,246 & & & 0,623 & 236,489 & 5,135 & & 131,411 & & 58,886 & 437,200 & 160,268 \\
\hline 7 & LVAd2 & 28,767 & & & & & & & & & 3,336 & 83,311 & \\
\hline 8 & LVAd3 & 2,257 & & & & 35,922 & 20,605 & & & & 16,625 & 344,879 & \\
\hline 9 & LVAd4 & $1.064,459$ & 2,270 & 5,050 & & 102,221 & 1,515 & & & & 112,978 & 421,723 & \\
\hline 10 & LVAd5 & 0,137 & & & & & & & & & 5,443 & 573,783 & \\
\hline 11 & LVAd6 & 137,271 & & 2,082 & & 227,405 & 594,136 & 0,425 & 0,823 & & 29,317 & 679,807 & \\
\hline 12 & LVAd7 & 91,179 & & & & 22,146 & & & & & 47,068 & 572,013 & \\
\hline 13 & LVAd8 & 157,497 & & & & & 0,001 & 16,429 & & & & 245,309 & \\
\hline 14 & LVd1 & $2.387,409$ & 8,104 & 54,173 & 151,463 & 220,001 & 122,586 & 411,918 & & 14,022 & 106,545 & $2.872,231$ & 14,411 \\
\hline 15 & LVd2 & 21,866 & & & & & 35,293 & 155,605 & & & & 48,436 & \\
\hline 16 & $\mathrm{LVd} 3$ & 7,268 & & & 34,001 & 38,144 & & & & & 0,236 & 41,766 & \\
\hline 17 & LVd4 & $1.411,638$ & 3,668 & 6,721 & 77,154 & 4,343 & 66,769 & & 211,403 & & 44,947 & 553,278 & \\
\hline 18 & Lvdf & & & & & & 19,413 & 12,690 & & & & & \\
\hline 19 & $\mathrm{LVe}$ & 49,378 & & & 53,905 & & & & & & 5,757 & 29,389 & \\
\hline 20 & PVAe & 13,470 & & & & 4,736 & & & & & & & \\
\hline 21 & RLd1 & $3.639,472$ & 16,928 & 45,466 & 226,955 & 540,800 & $1.528,271$ & 106,310 & 67,271 & & 17,189 & 64,464 & 40,774 \\
\hline 22 & RLd2 & 573,361 & 1,176 & 33,403 & 0,040 & $1.557,456$ & 135,375 & 0,317 & 31,845 & & 10,216 & 37,398 & \\
\hline 23 & RLd4 & 915,558 & & & 53,696 & & & & & 172,285 & 6,569 & 61,829 & 31,787 \\
\hline 24 & RLe1 & $1.064,637$ & 95,882 & 260,449 & 100,847 & 18,252 & 0,507 & & 9,179 & & 15,147 & 5,804 & 3,854 \\
\hline 25 & RLe2 & 628,587 & & 53,093 & 112,628 & 119,662 & 106,831 & 5,910 & 0,770 & 1,421 & 6,243 & 10,011 & \\
\hline 26 & RQg & & & & & & & & & & & 36,678 & \\
\hline 27 & RQo1 & 45,269 & & & & 312,860 & 896,527 & 0,536 & 0,450 & & 20,375 & 374,336 & \\
\hline 28 & RQo2 & 7,074 & & & & 148,908 & 27,207 & & & & 71,562 & 691,218 & \\
\hline 29 & RQo3 & 105,375 & & 3,601 & & 675,734 & $2.339,384$ & 21,727 & 51,677 & & 67,706 & 501,677 & \\
\hline 30 & RQo5 & 2,076 & & & & $1.142,005$ & 207,556 & & 10,193 & & 1,724 & 1,581 & \\
\hline 31 & RUbe2 & 289,092 & 1,104 & 7,646 & 11,215 & 78,160 & 1,719 & & & & $1.628,987$ & 202,818 & \\
\hline 32 & $\mathrm{Aqd} 3$ & & & & & 14,634 & & & & & & & \\
\hline
\end{tabular}

(Martins Jr. et al. 2006, Marques \& Martins Jr. 2004, Martins Jr. \& Vasconcelos 2008).

"Efetivamente, a direção para as opções sobre as áreas plantáveis para essas duas situações se apresenta atualmente sob foco de interesses políticos e econômicos nacionais e internacionais. $\mathrm{O}$ fato de que a população cresce no planeta, que mais pessoas possam comer melhor, de que o capital internacional atue de modo especulativo sobre os alimentos ante as pressões críticas dos preços da fonte de energia de maior energia (petróleo) faz com que as opções por terras necessitem obedecer à seguinte equação geral (Eq. 2):

$\mathrm{S} \mathrm{S}_{\mathrm{pAE}}{ }^{\circ} \mathrm{S}_{\mathrm{BH}}-\mathrm{S}_{\mathrm{Ad} \text { tradicionais }}-\mathrm{S}_{\mathrm{CVr}}-\mathrm{S}_{\mathrm{Ca}}+\left({ }_{\text {eventual fracãa }} \mathrm{S}_{\mathrm{Ad}}+\mathrm{S}_{\mathrm{P}}+\right.$
$\left.+{ }_{\text {arreas de semi ou total estabulamento do gado }} \mathrm{S}_{\mathrm{stEg}}<<\mathrm{S}_{\mathrm{P}}\right)-\mathrm{S}_{\mathrm{pa}} \pm \mathrm{S}_{\mathrm{m}}-\mathrm{S}_{\text {cfEE}}$ onde,

$\mathrm{S} \mathrm{S}_{\mathrm{pAE}}$ : área total plantável para produção de energia de biomassa e produção alimentar;

$\mathrm{S}_{\mathrm{BH}}$ : área total da bacia;

$\mathrm{S}_{\mathrm{Ad}}$ : áreas com agricultura;

$\mathrm{S}_{\mathrm{CVr}}$ : áreas de cobertura vegetal remanescentes e/ou legal;

$\mathrm{S}_{\mathrm{Ca}}$ : áreas de diferentes corpos d'água ou de sistemas hídricos;

$\mathrm{S}_{\mathrm{P}}$ : áreas de pastagens;

$\mathrm{S}_{\text {stEg }}$ : áreas de semiestabulamento do gado;

$\mathrm{S}_{\mathrm{m}}$ : áreas para mitigação;

$\mathrm{S}_{\mathrm{cfEE}}$ : áreas para corredores e maciços florestais ecológico-econômicos, naturais e reservas legais;

$\mathrm{S}_{\mathrm{pag}}$ : áreas de plantio de forragem para o gado" (ampliado de Martins Jr. \& Ferreira 2009). 
Tabela 9 - Relações principais entre rochas (siglas na Tab. 2), geoformas (siglas na Tab 3) e solos (siglas na Tab. 4) e materiais de origem (CETEC 1981, Martins Jr. et al. 2006)

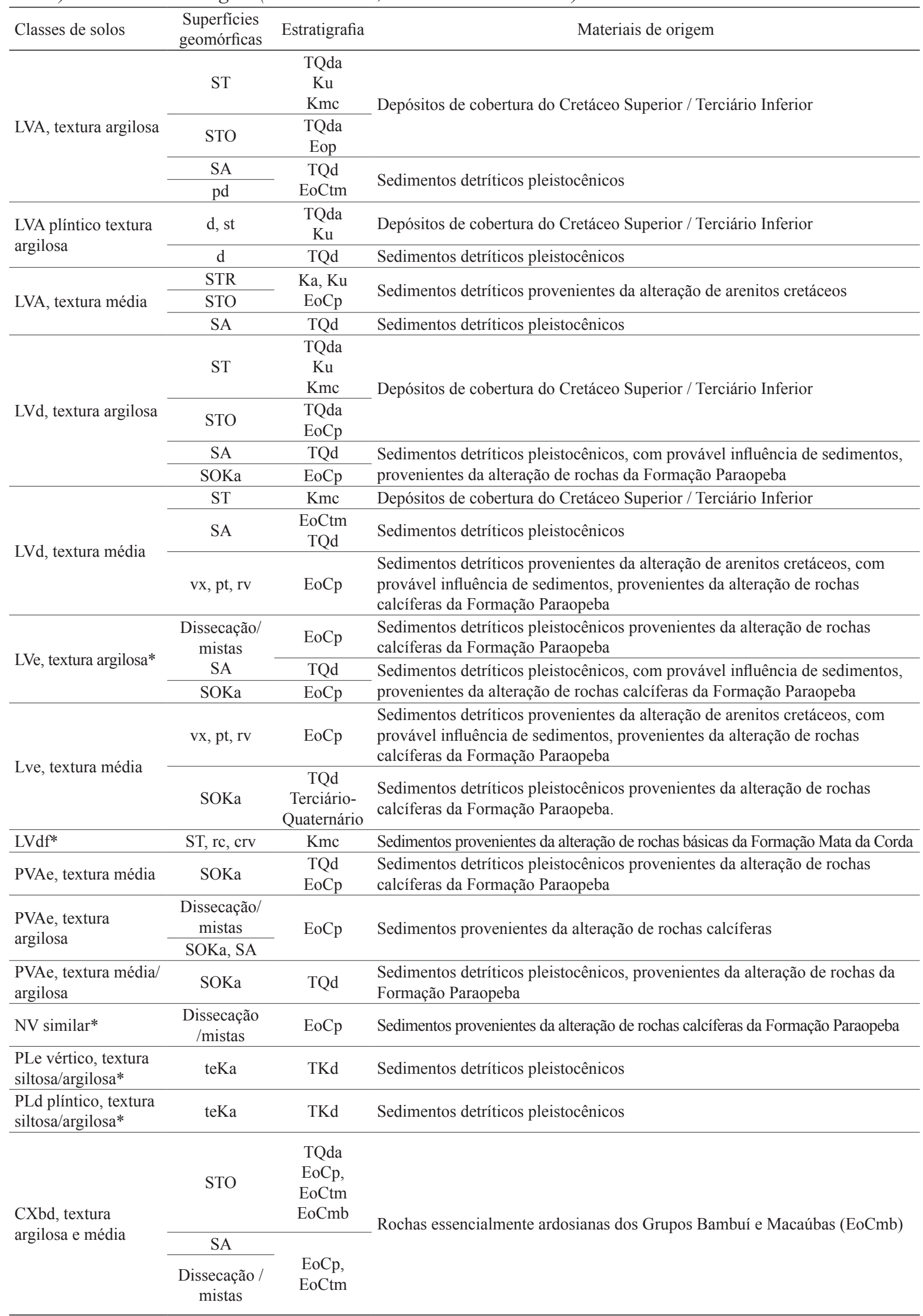


Tabela 9 - continuação

\begin{tabular}{|c|c|c|c|}
\hline Classes de solos & $\begin{array}{l}\text { Superfícies } \\
\text { geomórficas }\end{array}$ & Estratigrafia & Materiais de origem \\
\hline \multirow{4}{*}{$\begin{array}{l}\text { CXe, textura } \\
\text { argilosa* }\end{array}$} & SA - Soda & EoCp & \multirow{2}{*}{$\begin{array}{l}\text { Sedimentos detríticos pleistocênicos, provenientes da alteração de rochas } \\
\text { calcíferas da Formação Paraopeba }\end{array}$} \\
\hline & te & TQd & \\
\hline & tf, te & Qa & $\begin{array}{l}\text { Sedimentos detríticos pleistocênicos e recentes, provenientes da alteração de } \\
\text { rochas calcíferas da Formação Paraopeba }\end{array}$ \\
\hline & $\begin{array}{l}\text { Dissecação/ } \\
\text { mistas }\end{array}$ & EoCp & Rochas ardosianas e calcárias da Formação Paraopeba \\
\hline RLd & $\begin{array}{l}\text { Dissecação/ } \\
\text { mistas }\end{array}$ & $\begin{array}{c}\text { EoCp } \\
\text { EoCtm } \\
\text { PCc } \\
\mathrm{Ka}, \mathrm{mc}\end{array}$ & $\begin{array}{l}\text { Rochas essencialmente ardosianas, mas também quartzíticas e areníticas do } \\
\text { Pré-cambriano, Eocambriano e Cretáceo (formações Areado e Mata da Corda) }\end{array}$ \\
\hline RLd, concrecionário & $\begin{array}{l}\text { Dissecação/ } \\
\text { mistas }\end{array}$ & $\begin{array}{c}\text { EoCp, } \\
\text { EoCtm } \\
\text { PCc }\end{array}$ & $\begin{array}{l}\text { Rochas essencialmente ardosianas, provenientes do Grupo Bambuí, com influência } \\
\text { de materiais lateríticos, provenientes do desmonte de níveis de acumulação }\end{array}$ \\
\hline RLd arenoso & $\begin{array}{l}\text { Dissecação / } \\
\text { mistas }\end{array}$ & $\mathrm{Ka}, \mathrm{Ku}$ & Arenitos Cretáceos \\
\hline RLe* & $\begin{array}{l}\text { Dissecação / } \\
\text { mistas }\end{array}$ & EoCp & Rochas ardosianas e calcárias da Formação Paraopeba; EoCambiano Paraopeba \\
\hline GMd & VE & Qa & Sedimentos recentes colúvio-aluviais; Quaternário \\
\hline $\begin{array}{l}\text { GXbd, textura } \\
\text { argilosa }\end{array}$ & $\mathrm{d}$ & $\begin{array}{c}\text { TQda } \\
\text { Ku } \\
\text { TQd }\end{array}$ & $\begin{array}{l}\text { Depósitos de cobertura do Cretáceo Superior/Terciário Inferior; TQda } \\
\text { Terciário-Quaternário da; Ku Cretácio }\end{array}$ \\
\hline RQg & $\begin{array}{c}\mathrm{d} \\
\mathrm{SA}\end{array}$ & $\begin{array}{c}\text { TQd } \\
\text { EoCtm }\end{array}$ & Sedimentos detríticos pleistocênicos \\
\hline RUbe & $\mathrm{pt}, \mathrm{tf}$ & Qa & Sedimentos aluviais recentes \\
\hline \multirow{5}{*}{ RQo } & $\mathrm{d}$ & \multirow{2}{*}{ TQd } & Sedimentos detríticos pleistocênicos \\
\hline & SA & & - \\
\hline & STO & $\begin{array}{l}\text { EoCp, } \\
\text { EoCtm }\end{array}$ & \multirow{3}{*}{ - Sedimentos provenientes da alteração de arenitos cretáceos } \\
\hline & STR & & \\
\hline & Dissecação & Ka, Ku & \\
\hline $\mathrm{V}^{*}$ & Tf, pf, SA & TQd, Qa & $\begin{array}{l}\text { Sedimentos pleistocênicos e recentes, detríticos e aluviais, provenientes da } \\
\text { alteração de rochas calcíferas da Formação Paraopeba }\end{array}$ \\
\hline $\mathrm{NV}^{*}$ & st, rc, crv & Kmc & Sedimentos provenientes de rochas básicas da Formação Mata da Corda \\
\hline LVef* & st, rc, crv & Kmc & Sedimentos provenientes de rochas básicas da Formação Mata da Corda \\
\hline
\end{tabular}

Eqs. 1 e 2 são de aplicação direta para o processo de mensurar as áreas de uso e servem de base para equações complementares de cálculos sobre os tipos de usos e de produtividade em face das condições geoambientais e edáficas. Posteriormente, com considerações sobre a tecnologia agrícola e florestal aplicáveis.

\section{CONCLUSÕES A integração das relações} entre rochas/geoformas/solos/formações superficiais apresenta aspectos fundamentais para o planejamento regional (escalas de 1:1.000.000 a 1:100.000), servindo de base como método para aplicação a quaisquer outras bacias, mesmo aquelas com estruturas geológicas e litoestratigráficas bem distintas. Essas relações são de diversos tipos, especialmente tratando-se de questões que envolvem evidentes relações entre rochas/geoformas/solos e formações superficiais, as quais implicam na possibilidade de discernir: estabilidade versus instabilidade de terrenos; disponibilidade hídrica; declividades; estruturas dúcteis em relação às vertentes; estruturas rúpteis e aspectos do processo de infiltração da água pluvial; relações entre infiltração e escoamento superficial imediato pós-chuvas com ou sem desmatamento e onde a agricultura seja, ou não, organizada com métodos conservacionistas; suscetibilidade a processos de "perda universal de solos" (Wischmeyer et al. 1958, Wischmeyer \& Smith 1965, 1978), com atualizações ao método como desenvolvido para o Brasil por Bertoni et al. (1975) e Lombardi Neto (1977) e suscetibilidade de indução ao processo erosivo, entre muitos outros aspectos.

A separação de terras feitas do regional ao local é um procedimento fundamental para, de início, se descortinar áreas mais propícias e adequadas do ponto de vista ambiental à produção agrícola, em 
especial, bem como aquelas regiões para mitigação, conservação e/ou preservação em bacias como a do Paracatu em avançado estágio de ocupação. A questão se fechará com as etapas seguintes, as quais, mediante o espectro de possibilidades extraídos dessa etapa inicial, emergem ao se analisar, então, as condições geotécnicas, edáficas, hídricas e de relevo das áreas reconhecidas como passíveis de uso sustentável, obviamente considerando as técnicas de uso e de conservação com seus custos operacionais.

As bases cartográficas da bacia do Rio Paracatu servem de exemplo para compreensão da gestão de territórios, sejam no meio acadêmico, em entidades governamentais, em comitês de bacias hidrográficas ou em empreendimentos privados.

As relações quantificadas entre rochas, geoformas, solos e formações superficiais apresentam-se como uma contribuição fundamental para comprovar a pertinência dos processos de morfogênese e pedogênese no âmbito de decisões sobre usos da terra. Também devem ser úteis para futuros mapeamentos e demais estudos de campo, por permitirem inferências indiretas prováveis a partir de elementos de rochas, solos e geoformas, aplicáveis a projetos agrícolas e estudos de compatibilidade de plantios para produção de energia de biomassa de forma compatível com os terrenos. Tais aspectos, por não serem triviais, demandam dos geocientistas, em colaboração com os engenheiros agrônomos, florestais e ambientais, a competência de estabelecer regras em diversas escalas de análise para poder decidir os melhores modos de ocupar o terreno em função do substrato. Evidentemente, muitos outros fatores deverão ser confrontados, porém as relações entre rochas, geoformas, solos e formações superficiais são os primeiros fatores a serem considerados para se estabelecer os modelos e os cenários do DUOT de qualquer bacia hidrográfica.

AGRADECIMENTOS Ao Ministério da Ciência, Tecnologia e Inovação (MCT), FINEP, Fundo Setorial CT-Hidro-2002, Projeto CRHA (2003-2006). Ao Conselho Nacional de Desenvolvimento Científico e Tecnológico (CNPq), Projeto ACEE, 2005-2008; Fundação de Amparo à Pesquisa do Estado de Minas Gerais (FAPEMIG), Projeto SACD, 2010-2012.

\section{Referências}

Almeida F.F.M. 1977. Evolução Tectônica do Centro Oeste Brasileiro no Proterozóico. In: Anais da Academia Brasileira de Ciências, Rio de Janeiro, p. 285-295.

Bertoni J., Lombardi Neto F., Benatti Jr. R. 1975. Equações de Perdas de Solo. Boletim Técnico do Instituto Agronômico 21, Campinas, São Paulo, p. 1-25.

CETEC. 1981. II Plano de Desenvolvimento Integrado do Noroeste Mineiro: Recursos Naturais. Belo Horizonte: Fundação Centro Tecnológico de Minas Gerais CETEC-MG.

EMBRAPA. 1999. Centro Nacional de Pesquisa de Solos (Rio de Janeiro, RJ). Sistema Brasileiro de Classificação de Solos. Brasília: EMBRAPA Produção da Informação, Rio de Janeiro: Embrapa Solos. 412 p.

Lombardi Neto F. 1977. Rainfall erosivity: its distribution and relationship with soil loss at Campinas, Brazil. Ph.D.Thesis, Purdue University, USA, 53 p.

Marques A.F.S.M., Martins Jr. P.P. 2004. Organização dos Atributos de Solos em um Sistema Lógico de Conhecimento paraDecisãono SisDec AGRO-HYDROS. Memória Técnica CETEC: Nota Técnica NT CRHA 08/2004. Disponível em: www.cetec.br/crha. Acesso em: 08/10/2009.

Martins Jr. P.P. 1998. Fundamentos Conceituais para o Desenvolvimento e a Prática das Geociências Agrárias e Ambientais. A Terra em Revista, 4:10-15.

Martins Jr. P.P. 2000. Epistemologia Fundamental. Um Estudo Introdutório sobre a Estrutura do Conhecimento e a
Aplicação Prática da Epistemologia na Pesquisa Científica. Belo Horizonte: Fundação CETEC e Universidade Federal de Ouro Preto. Apostila Pré-livro. 169 p.

Martins Jr. P.P., Ferreira O.C., Novaes L.A., Vasconcelos V.V. 2006. Conservação de Recurso Hídrico no Âmbito da Gestão Ambiental e Agrícola de Bacia Hidrográfica. Projeto CRHA. Belo Horizonte e Ouro Preto: Relatório Final. Memória Técnica do CETEC. Disponível em: www.cetec.br/crha. Acesso em: 20/02/2010.

Martins Junior P.P. \& Vasconcelos V.V. 2008. Protótipo de Sistema Especialista para Auxílio à Decisão em Direito Geo-Ambiental: Situações de Desmatamentos Rurais. Sistema Especialista-IA-Meio-ambiente. Revista Climatologia e Paisagem - CLIMEP, 3(2):48-66. Disponível em: http://www.periodicos. rc.biblioteca.unesp.br/index.php/climatologia/article/ viewFile/1789/2206. Acesso em: 20/01/2010.

Martins Junior P.P., Carneiro J.A., Cambraia J.A., Pereira J.S., Paiva D.A. 2008. Arquitetura de Conhecimentos em Ecologia-economia para Gestão Ambiental de Bacia Hidrográfica. Belo Horizonte: CNPq/CETEC, Relatório Final. 237 p.

Martins Junior P.P. \& Ferreira O.C. 2009. Zoneamento Econômico de Territórios de Bacias Hidrográficas Importância Ecológica. Revista Economia \& Energia ECEN, n. 71, Dez./2008-Jan/2009. Ano XI. p.: 2338. Meio digital e impresso. (Em Português e Inglês). ISSN 1518-2932. 
Martins Junior P.P., Ferreira O.C., Vasconcelos V.V., Jano D.R. 2010. Zoneamento Ecológico-Econômico e Desenho de Uso Optimal dos Territórios de Bacias Hidrográficas. Rio de Janeiro: Revista Economia \& Energia, ECEN. ISSN 1518-2932. Disponível em: http://ecen.com. Acesso em: 23/01/2010.

RURALMINAS. 1996. Plano Diretor de Recursos Hídricos da Bacia do Rio Paracatu - PLANPAR. Consórcio MAGNA / DAM / EYSER, Governo de Federal, Governo do Estado de Minas Gerais, Governo do Distrito Federal, Brasil.

Wischmeier W.H., Smith D.D., Uhland R.E. 1958. Evaluation of factors in soil equations. Agronomic Engineering, 39(474):458-4622.
Wischmeier W.H. \& Smith D.D. 1981. Predicting rainfall erosion losses - a guide to conservation planning. NCRS US Department of Agriculture. Agriculture Handbook, 537, 56 p.

Wischmeier W.H. \& Smith D.D. 1965. Predicting rainfallerosion losses from cropland east of the Rocky Mountains. NCRS US Department of Agriculture. Agriculture Handbook, No. 282, 47 p.

Manuscrito ID 17490 Recebido em: 14/05/2010 Aprovado em: 28/06/2012 